\title{
Erratum to image guided thermal ablation in lung cancer treatment
}

doi: $10.21037 /$ jtd-2021-03

View this article at: http://dx.doi.org/10.21037/jtd-2021-03

Erratum to: J Thorac Dis 2020;12:7039-47

Image guided thermal ablation in lung cancer treatment

This article that appeared on Page: 7039-7047, Vol 12, No 11 (November 2020) Issue of the Fournal of Thoracic Disease (7TD) (1), contained an incorrect version that did not include some grammatical changes and a figure was missed. The online article and PDF have since been updated.

The publisher regrets the error.

Open Access Statement: This is an Open Access article distributed in accordance with the Creative Commons AttributionNonCommercial-NoDerivs 4.0 International License (CC BY-NC-ND 4.0), which permits the non-commercial replication and distribution of the article with the strict proviso that no changes or edits are made and the original work is properly cited (including links to both the formal publication through the relevant DOI and the license). See: https://creativecommons.org/ licenses/by-nc-nd/4.0/.

\section{References}

1. Lin M, Eiken P, Blackmon S. Image guided thermal ablation in lung cancer treatment. J Thorac Dis 2020;12:7039-47.

Cite this article as: Erratum to image guided thermal ablation in lung cancer treatment. J Thorac Dis 2021;13(1):502. doi: $10.21037 /$ jtd-2021-03 